UNIVERSITÀ DEGLI STUDI DI TRENTO

Facoltà di Sociologia

\title{
Constitutionalism and Constitutional Anomie in the New Europe
}

\author{
Paul Blokker
}

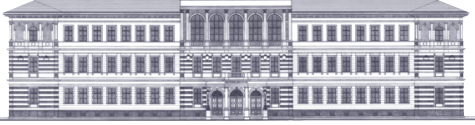

DIPARTIMENTO DI SOCIOLOGIA E RICERCA SOCIALE 
DIPARTIMENTO DI SOCIOLOGIA E RICERCA SOCIALE QUADERNI 

CONSTITUTIONALISM AND CONSTITUTIONAL

ANOMIE IN THE NEW EUROPE

PAUl BLOKKER

QUADERNO 53

Novembre 2010 


\section{Acknowledgement}

The author acknowledges a post-doctoral fellowship of the Provincia Autonoma di Trento (PAT), held at the department of Sociology and Social Research, University of Trento, Italy. 


\section{CONTENTS}

1. Introduction

p. 7

2. New Constitutionalism in the New Europe

3. Tensions in Modern Constitutionalism 13

The Problématique of State-Centrism 14

The Problématique of Cultural Diversity 14

The Problématique of Depoliticization 16

The Problématique of Civic Exclusion 19

4. Exploring Democratic Potentialities 21

Four Tensions 22

Possible Remedies? 24

5. Concluding Remarks 36

$\begin{array}{ll}\text { References } & 39\end{array}$ 



\section{Introduction ${ }^{1}$}

The recent (re-)establishment of constitutional democracies in Central and Eastern Europe is subject to a number of paradoxical phenomena. There is the tension suggested by Pierre Rosanvallon, regarding the state of democracy, i.e. '[h]ow to understand the turning point of the 1990s, which strangely saw the disenchantment with the life of democracies grow at the very moment that the fall of communism seemed to vindicate their supremacy?' [2006, 189]. In a slightly different sense, Dick Howard has argued that 'the revolutions of 1989 have to "catchup" with the Western model of the nation-state, just at the moment when, according to Habermas's notion of "constitutional patriotism", that traditional model has supposedly lost its hold!' [Howard 1995, 1428]. These tensions can be equally put for modern constitutionalism [cf. Walker 2002], i.e., how to understand the confirmation of the global rise and expansion of constitutionalism in the 'legal revolutions' of 1989, at the very moment that an increasing disenchantment with and challenges to modern constitutionalism have become visible? These three tensions - that of the apparent obsoletion of liberal democracy, of national sovereignty, and of modern constitutionalism - and in particular the last one, will inform the rest of the paper.

I will focus in particular on the obsoleteness or crisis of recently introduced modern constitutionalism in the new EU member states (although the problématiques I discuss have wider implications for modern constitutionalism in Europe). The obsoleteness or crisis of constitutionalism I am alluding to has some affinities with Emile Durkheim's notion of 'anomie'. In Durkheim's view, anomie emerges in a situation of an absence of regulation of social relationships, resulting in declining social solidarity [Durkheim 1997, 304]. Anomie is then about a disjunction between the legal and the social [Augenstein and

${ }^{1}$ Earlier versions of this paper have been presented at the workshop 'Democracy, Freedom and Imperialism: Debating James Tully's Public Philosophy in a New Key', EUI, Florence, 21-22 September 2009, the 9th Conference of the European Sociological Association, 'European Society or European Societies?', Lisbon, 2-5 September, 2009, and in the Seminar Series-Post-Doctoral Researchers PAT, Department of Sociology and Social Resarch, University of Trento, 25 February, 2010 
Hendry 2009, fn 24]. With regard to the problématique of modern constitutionalism in contemporary Europe, there is arguably a situation of anomie in the sense that there seems to exist a profound mismatch between existing institutions, institutionalised models and norms, and imaginaries (here designated as modern, Westphalian constitutionalism based on a unitary nation-state) and a rapidly changing political and societal context that does in crucial ways not correspond to an institutionalised, Westphalian framework. In other words, there are a number of clear discrepancies between institutions and society. This disjunction seems to be particularly evident in the landscape of the recently established constitutional democracies in Central and Eastern Europe.

On the one hand, and to rephrase the tension affecting modern and national constitutionalism, it has often been argued that the constitutional transformations since 1989 (or, more accurately, since the late 1970s) [cf. Irena Grudzinska-Gross 1997; Sajó 1990], have strengthened - and even amplified [Arjomand 2003] - international tendencies in the form of 'rights revolutions' [Přibáň \& Sadurski 2006], and their crystallization into a reinvigorated, 'new constitutionalism'. New constitutionalism is grounded in national sovereignty and constitutional democracy, the idea of fundamental rights and the notion of the rule of law, while the most important 'new' element is the protection of the constitution by an independent guardian, i.e., through judicial review by constitutional courts. In this sense, the East reinforces and 'amplifies' longer term Western (European) and global traditions of constitutional democracy and human rights that have emerged most forcefully since the Second World War, and in which the balance of constitutional democracy is increasingly on the former rather than the latter component.

On the other hand, the return to constitutionalism and liberal democracy of the region comes at a specific moment in world history in which nation-state based and monist constitutionalism or 'modern constitutionalism' [Tully 1995] can be seen as increasingly problematic and challenged, and as subject to a variety of tensions and the centrifugal pressures of fragmentation. Homogeneity and coherence, elements which are at the core of traditional constitutional democracy, are under strain due to 
inroads into national sovereignty of a supranational and subnational kind (notably through EU integration and regional governance respectively, as well as a plurality of relevant actors). Further tensions result from a variety of calls for self-rule and cultural recognition, and more profoundly, due to the increasingly untenable and anachronistic, but immanent tendencies to homogenization and centralization in the modern constitutional ontology [cf. Tully 1995] that run counter to tendencies of pluralization and post-nationalism.

In a related way, constitutional, representative democracy is increasingly seen as failing to respond to challenges to its promise of democracy and popular sovereignty. The latter can be summed up as a 'democratic deficit', in that populist critique of the political status quo, and calls for more civic voice, participation and local government, as well as claims for recognition and plurality in the context of identity politics, are widespread, but existing forms of constitutional democracy seem to lack in the means of responding adequately to such demands.

The paper will proceed as follows. I will first briefly analyse to what extent it can be claimed that the new constitutionalism adopted in the former communist countries is a reinvigorated version of Westphalian, modern constitutionalism. To the extent that this seems indeed to be the case, I will, secondly, outline a number of problématiques or tensions that affect modern constitutionalism in the current European context, and that contribute to a situation of constitutional anomie. These include four problématiques in particular: state-centrism, cultural diversity, depoliticization, and civic exclusion. In the third section, I will (tentatively) discuss possible solutions to or ways out of these four problématiques by hinting at, in a descriptive sense, insufficiently (or un-)explored dimensions of the Central and Eastern European constitutions that might, if made visible and reinforced, counter at least some of the problématiques. And in a more normative sense, I will at the same time indicate possible steps towards constitutional change that would, in my view, make current constitutional orders more amenable to challenges of pluralism, democratic legitimacy, and post-nationalism. What is more, these steps point at a - in my view - salient and overdue transformation 
of modern constitutionalism as such, making it more compatible with democracy and civic inclusion and participation.

\section{New Constitutionalism in the New Europe}

The 'modern' character of constitutionalism in Central and Eastern Europe can be corroborated by at least four aspects: an exceptional emphasis on legalism, a prominence of fundamental rights, an emphasis on an integrative, symbolic constitutional dimension, and the articulation of a strong break with the past by means of constitutions. First, the establishment of constitutional democracies in post-communist Europe followed the region-wide 'legal revolutions' and involved an unusually strong emphasis on legality and the legal (as opposed to revolutionary) character of the changes [cf. Arjomand 2003; Häberle 1992; Přibáň \& Sadurski 2006]. A main reason for this emphasis on legalism, legal continuity, and the rule of law is deemed to have emerged as an antidote to the 'ideological' [Arjomand] or 'contradictory' [Přibán and Sadurski] socialist legality of the communist regimes. As argued by Said Amir Arjomand:

The abuse of 'legality' by Communism and Fascism necessitated a new, amplified, rights-based conception of the rule of law, which includes justiciable human rights substantively, and specifies mechanisms and institutional devices for safeguarding the rule of law - most notably the constitutional courts, and in some countries, additionally, the office of the Ombudsperson. It has been noted... that while the Americanstyle, 'diffuse' judicial review appears as a good guarantor of the rule of law in the old, narrow sense, the constitutional courts, modeled on Kelsen's design in the Austrian Constitution of 1920 but with a very significant extension, have lent themselves admirably to the guarantee of the rule of law in the new, amplified sense. The key to the role of the constitutional court as the instrument of the new constitutionalism is the idea of transition to democracy - first in post-Fascist Germany and Italy, then in post-authoritarian southern Europe, and finally in postCommunist Eastern Europe and Russia. The idea, and the institution of constitutional courts, became all the more attractive after 1989 as it held the promise of joining Europe. 
Second, and in a related way, the revolutions of 1989 can be understood as 'rights revolutions', in the sense that a main element in the struggle against communism was the dissident claim for the recognition of European and international rights standards [Přibán \& Sadurski 2006]. What makes the new constitutional democracies in Central and Eastern Europe somewhat different if not in kind but at least in degree - from existing, 'old' democracies is an unusually strong emphasis on additional safeguards for human rights and rule of law protection, and the facilitation of democratization through constitutionalization [Arjomand 2003; Sadurski 2005]. In this reading, the main aims of the political and constitutional transformations were a kind of appropriation, reproduction, inculcation, and safeguarding of prevalent understandings of constitutional democracy, through the establishment of independent democratic regimes with full and uncontested national sovereignty [cf. Offe 1996], and the creation of coherent and clearly confined legal systems, based on the 'higher' law of the constitution and the idea of the protection of rights.

Third, the latter did, however, not only entail the (re-) foundation of enforceable legal systems, with the appropriate institutional division of labour, and independent status of the judicial system and foundational rules of the constitution, but also, in cultural-sociological terms, the stimulation of cohesion and integration around a common identity [Přibán 2007]. In the latter sense, the new constitutions could also be seen as vehicles of integration of the fragmented and conflictive post-communist societies. Also in the latter regard, the new constitutions can be regarded as recreating an existing, Westphalian model of national constitutional states that, in order to be legitimate and socially embedded, express a homogeneous, national language of identity, history, and tradition [cf. Přibáň 2007; Häberle 1992]. In the legalinstitutional as well as cultural-identitarian senses, the legal revolutions in the East constitute both a renewed entrance into the Western, capitalist and democratic world as well as the constitution of particularist, national political communities. 
Fourth, it is common, even if not entirely accurate $^{2}$, to understand the Central and Eastern European revolutions of 1989 as having resulted in a strong break with the unconstitutional, communist past. As among others James Tully has argued, a main characteristic that differentiates 'modern' from 'ancient' constitutionalism is the former's pretension to a complete break with the past [Tully 1995; cf. Ackerman 1992; Hart 2003]. In other words, modern constitutionalism understands the constitution as a foundational document that establishes a completely new order that is radically distinct from the preceding one. Even if a significantly novel tendency in the 1989 revolutions was that of 'legal continuity' [cf. Arato 2000], implying a less than complete rupture with the existing legal orders, it can be argued that de facto the new constitutions have been interpreted as the foundations of an entirely new, or at least radically dissimilar, political, economic, and cultural order ${ }^{3}$.

To sum up, the Central and Eastern European constitutions can be understood in at least four ways - as institutional constellations, as reflections of fundamental rights, as expressing national unity and identity, and as providing a clear rupture with the past - as a return to, and replications of modern, known forms of constitutionalism. In this reading, the re-emergence of modern constitutionalism in these countries has led to the (re-)

2 As far as I can see, the full history of the 'rights revolutions' in the region still needs to be written, in that, as accurately noted by Irena Grudzinska-Gross [1997], the convergence of both dissidents and communist reformers towards a legal language made such rights revolutions possible, and therefore, a binary view which counterposes post1989 democratization and constitutionalization to pre-1989 arbitrariness and 'fake legality' seems not to do justice to historical developments. On a different note, a singular emphasis on the rights and rule of law dimensions of the constitutions in the new democracies might further have the defect of leading away attention from the substantial diversity and plurality of constitutional perceptions that can be found in the constitutions of the region [see chapters 5-7 in Blokker 2009a].

${ }^{3}$ Even in the case of Hungary, where an entirely new constitutional document was never adopted, and the democratic constitution of the post-1989 democratic state consists of an (admittedly radical) re-interpretation and extensive amendment of the Communist constitution, the post-1989 constitution has been understood as ultimately adding up to a far-going rupture with the past and as stipulating the foundational rules of the current democratic regime. It can, however, be argued that exactly in the case of Hungary, where one could argue modern constitutionalism, in particular in the guise of new constitutionalism, took hold most strongly, a powerful counternarrative of constitutionalism has emerged that in a number of ways invokes ancient rather than modern constitutionalism [Scheppele 2004; cf. Blokker 2009a]. 
establishment of a classical, Westphalian type of nation-state with clear-cut constitutional orders and partaking in an international society of states 4 .

\section{Tensions in Modern Constitutionalism}

In the light of the four characteristics described above, it seems then reasonable to understand the Central and Eastern European constitutions as for a good part, if perhaps not exclusively, as having been set up within the Western, modern tradition of constitutionalism [cf. Piana 2006], and in some dimensions as even more orthodox or extensive. This grounding in a modern constitutional approach of Central and Eastern European constitutional orders might then logically be understood as subject to the tendencies of erosion and disenchantment that equally seem to affect Western European constitutional orders. In other words, the phenomenon of constitutional anomie, i.e., an incongruence between political and social realities and constitutional-legal structures, as can be observed in established democratic societies [cf. Walker 2002; Rosanvallon 2006], seems particularly relevant in the context of new constitutional democracies.

Four problématiques can be outlined that affect the constitutional orders in the new democracies. These problématiques are equally compromising modern constitutionalism in more 'advanced' democracies [cf. Blokker forthcoming a], but the discussion here will focus on the more fragile regimes of the new democracies. The four problématiques discussed are: state-centrism, cultural diversity, depoliticization, and participation.

4 This argument is further corroborated by the suggestion that many of the constitutions in the region took a rather 'souverainist' turn by explicitly emphasising the protection of national sovereignty and independence in the new constitutional documents (partially as a reaction to previous subjection to the Soviet Union) [Albi 2005]. A further indication of the attachment to a modern form of constitutionalism - and partially in contradiction to developments of Europeanization - is the recent following of the German pattern of national constitutionalism by a number of Constitutional Courts in the region [cf. Sadurski 2008]. 


\section{The Problématique of State-Centrism}

One of the most widely discussed problems of modern, Westphalian constitutionalism is its explicit grounding in the modern state [Walker 2002; 2008]. Apart from the historical injustices and forms of political violence that were at the basis of the formation of modern state, and that can be understood as having structurally compromised modern constitutionalism [cf. Tully 1995], it can be argued that the state-centred nature of modern constitutionalism is a key problem in current times of poly-centric globalization, in that it seems to correspond less and less to political and legal reality, in particular so within the complex context of European integration. In this regard, the "souverainist" constitutional projects of the new democracies [Albi 2005] can be seen as subject to eroding tendencies, such as the transfer of elements of sovereignty to the European level, as well as tendencies into the opposite direction, i.e., the transfer of prerogatives to the regional and local levels. Despite tendencies to the contrary ${ }^{5}$, the eroding trends seem part of a structural trend that will perhaps not so much undermine state sovereignty altogether, but certainly contributes to its modification, not least in terms of the fragmentation of sovereignty and the multiplication of its sites [cf. Rosanvallon 2006; Walker 2008].

Complicating factors in the case of the new democracies include the recent retrieval of autonomy in the region and a resulting strong emphasis on sovereignty and independence [Albi 2007], and the related problem of a legacy of 'socialist legality' and relatively weakly embedded democratic-constitutional and democratic-political cultures [cf. Sajó 2005].

\section{The Problématique of Cultural Diversity}

A second problem that affects all European societies but can be said to have deeper and more complex historical roots in Central and Eastern Europe is that of cultural pluralism and diversity. As Tully [1995] as well as others [MacDonald 1995] have argued, modern constitutionalism has an immanent tendency to

${ }^{5}$ See, e.g., the recent decision of the German Bundesverfassungsgericht on the Lisbon Treaty (see the special issue of the German Law Journal 2009, 10(8); for the new democracies) [see Albi 2007; Sadurski 2008; Pŕibáň 2010]. 
promote cultural homogenization and assimilation, and has a certain difficulty in dealing with cultural diversity and multiculturalism. In the words of James Tully, 'modern constitutionalism comprises three concepts of popular sovereignty which eliminate cultural diversity as a constitutive aspects of politics. The people are sovereign and culturally homogeneous in the sense that culture is irrelevant, capable of being transcended, or uniform' [1995, 63]. But it is by now equally a commonplace that modern constitutionalism cannot function without a 'civic religion' that is based on narratives of national belonging, cultural homogeneity, and a 'conscience collective' and is in need of a rather clear-cut hierarchy of authority and internal sovereignty [cf. MacDonald 1995, 3-4; Tully 1995].

Two main (but problematic) approaches to cultural diversity stand out in the modern constitutional tradition. The first, the liberal tradition, has often been accused of ignoring cultural diversity in its endorsement of the idea of a neutral state. While cultural diversity is not necessarily explicitly repressed in the case of classical liberalism, its institutions and rules will tend to either implicitly favour the majority [cf. Kymlicka \& Opalski 2001] or, at the very least, be inimical to questions of either cultural identity or cultural recognition. The second tradition, that of nationalism, explicitly favours a homogeneous, majority cultural identity as the basis of a stable constitutional order, but, in this, subjects or assimilates other, minority cultures to the majoritarian ideal.

It is particularly the latter tradition that has often been seen as prominent in the new democracies [Přibán 2007]. In most, if not all, constitutional debates in the region, protracted conflict has emerged between those that favour a neutral, liberal definition of national identity, and those that promote more particular, cultural understandings (the latter include representatives from both majority and minority groups). What makes the picture more complicated are evidently the claims of minority groups, often of a longstanding nature, which contest majoritarian and homogeneous definitions (either implicitly or explicitly so) of the newly established democratic states (the most clear-cut examples 
are probably Romania ${ }^{6}$, Slovakia, and former Yugoslavia, but also Latvia and Lithuania) ${ }^{7}$.

\section{The Problématique of Depoliticization}

The novelty of 'new constitutionalism' in the post-communist region can be identified in a number of more or less shared, regionwide tendencies [Sadurski 2005]. First, there is the emergence of a level of judicialization of democratic politics, in particular in terms of Constitutional Courts acting as the guardians of the constitution as well as protectors of pre-political, fundamental rights. Secondly, an unusally strong emphasis on a legal language - if not always practice - of fundamental rights and a singular, monist view of constitutionalism have emerged. As noted earlier, both the politically substitutive role of Constitutional Courts and the strong attachment to legal constitutionalism and fundamental rights can be understood in the specific context of democratic transition [cf. Arjomand 2003; Sadurski 2005]. A third element which is not usually deemed part of the notion of 'new constitutionalism' (which is anyhow applied also beyond the European context), but can be seen as amplifying some of its dimensions in the specific case of Central and Eastern Europe, is EU accession and membership. In terms of the joining of a wider pre-political rights consensus, the attempt to provide an external 'anchor' to the new democracies through EU membership, and a further entrenching of Constitutional Courts,

${ }^{6}$ A case in point is the constitutional debate in Romania in the early $1990 \mathrm{~s}$, and again in 2003, in which a structural conflict between the Hungarian minority and the Romanian majority over the definition of the state as either national or multinational was prominent [cf. Blokker 2009a; Preda 2002]. As late as 2003, a representative of the Hungarian minority in Romania argued the following during the debate on constitutional revision: Thus, we believe that the national character of the state has been exceeded by history, it has become anachronistic. It is known that we criticized the syntagm of "national state" also in 1991, remaining consistent in this opinion, as it is a political category that has fulfilled its historical role, and has become dissonant with a modern Constitution, and we can specify that nothing similar appears in European fundamental laws, in the states of Europe [Dezbateri parlamentare, 18 June 2003; my translation].

7 The solution that has been offered by those that propose a kind of third way in the form of 'liberal nationalism' (see, in particular, the works of Will Kymlicka) is not convincing in all respects [Blokker 2008]. 
EU membership can be seen as contributing to a specific - legal understanding of constitutionalism ${ }^{8}$ [Piana 2006].

The prominence of the role of independent Constitutional Courts in the region has been widely debated [cf. Schwartz 2000]. From a critical point of view, it can be argued that the main features of 'new constitutionalism' overlap with what Richard Bellamy has labelled 'legal constitutionalism', and consist in the idea that constitutions 'enshrine and secure the rights central to a democratic society', and are understood as forms of 'higher law' which are difficult if not altogether impossible to change by political means. Moreover, the idea is that distinct judicial institutions and experts are best capable of defending and interpreting the constitution [Bellamy 2007, 1]. This form of 'democracy by judiciary' finds two main forms of justification. First of all, the idea is that the post-communist societies are wanting in terms of both capable political and civil actors, and that independent, constitutional judges are the ones most capable of leading the new democracies into the direction of 'normal democracies'. Second, it is sometimes argued that judicial review by independent constitutional experts might actually enhance the substance of democratic politics, thus considered a form of 'democratizing democracy' [cf. Sadurski 2005, 12-13; Scheppele 2005].

In a very much related way, a widespread, if not dominant, interpretation of constitutionalism in the region is informed by what I have called elsewhere the 'ethic of rights', i.e., the idea that identifies democracy with the liberal model of constitutional democracy based on (natural) rights, legal procedures, and the equality of citizens before the law [cf. Delanty 2000; Ferry \& Renaut 1992; Přibán 2005b, 308-09]. This monistic view of constitutional democracy often not only reduces democracy to liberal democracy, but also understands a specific set of

${ }^{8}$ This is corroborated by Sajó [2005: 251-2], who argues that membership in the Union increases constitutional precommitment at the national constitutional level, since many constitutional elements that exist in the domestic constitution (human rights guarantees, for example, as seen by the impact of the anti-discrimination directive) are now beyond the reach of national majorities. Further, many constitutional elements are protected by European institutions that are independent of domestic politics. 
(predefined) rights and their protection as its main aim9. A general trend in the constitutionalization of the region has been the interpretation of constitutions as vehicles of relatively unequivocal pre-political rights and values, and, in this, the absence of wider political and public debates on the foundations of the existing constitutions. As Sadurski has pointed out,

in the process of anointing constitutional courts as the sole holders of constitutional virtue, an important insight has been lost: all the organs of the state - including the elected branches - are obliged to interpret and respect the Constitution, and there may be reasonable disagreements between people of good will (and, consequently, between various institutions empowered and obliged to conduct constitutional interpretation in the process of performing their constitutional duties) about what the Constitution really means [cf. Sadurski 2003b, 13].

In other words, constitutions have been mostly understood as foundational documents that merely need interpretation by specialized institutions, notably Constitutional Courts, and much less so as vehicles of continuing dialogue over foundational values and rights, and the overall nature of the political community.

The third element mentioned, EU membership, adds in some ways to the predominance of a legal constitutionalist tendency by embedding the new democracies in the wider EU community of law and constitutionalism, further entrenching a depoliticized, legal discourse. The political and legal conditionality that was part of the enlargement process meant that an external dimension played a strong role in the (re-)design of national democratic regimes. What is more, EU accession has also contributed to an enhanced standing of Constitutional Courts in their own national arenas as a kind of gatekeepers [Sadurski 2008, 3].

These features of a distinctive, insulated constitutionalism in the region - the judicialization of politics, rights foundationalism, and European constitutionalism - are clearly not without problems and not beyond contestation. Indeed, depending on one's view, new constitutionalism can be seen in all three

9 This is perhaps most clearly illustrated by Laszlo Solyom's (the former Chief Justice of the Hungarian Constitutional Court, and former president of Hungary) invocation of the Constitutional Court's role in protecting the 'invisible constitution'. 
dimensions as both enhancing, or, alternatively, as compromising constitutional democracy. But, be that as it may, it seems hard to deny that the three features or tendencies indicate the wider potential danger of an overall depoliticized and essentialistic view of democratic politics that denies any role of the larger demos and civil society, and its representatives, in playing a role in the definition of the foundational, ethical values that provide the constitutional context of the new democratic orders. This danger can be exemplified by the unusually expansionary or activist role of (some of the) Constitutional Courts in the region (in particular the Hungarian, Polish, and Czech ones), which has often been interpreted as a necessary but temporary substitute for weak civil societies and weak party systems in a process of transition to democracy. However, apart from the fact that a judicialized type of politics might become a self-perpetuating system rather than a temporary anomality [cf. Sadurski 2005], the substitution per se of democratic politics by a radically independent and unaccountable judicial institution can be seen to indicate an original sin that fatally compromises democracy as popular self-rule, and therefore fails in important ways to institutionalize a participatory democratic regime.

\section{The Problématique of Civic Exclusion}

The 'original sin' referred to above indicates a one-sided interpretation of constitutional democracy in which the constitution is seen (almost) exclusively as a limiting and ordering device, and only to a lesser extent as also an enabling and participatory device, promoting popular self-rule. The latter dimension appears to have played a much less important, even if not insignificant, role in post-communist constitution-making. The general tendency in the region has been constitutionalization by means of the drawing up of rights-based, liberal-inspired texts, and a strong entrenchment of the rule of law and fundamental rights, as well as to various extents the expression of a strong identity-based, communitarian dimension. Such a strong emphasis on the rule of law and rights entrenchment was not least the outcome of political action by the dissident movements in the region [Přibáň 2005a]. 
The civic dimension of the dissident legacy - that regarding participation and political activism of civil society - seems, however, less prominently institutionalized in the post-communist constitutional orders ${ }^{10}$. While the strong rights dimension admittedly includes a participatory dimension by means of the institutionalization of political and participatory rights [cf. Přibán \& Sadurksi 2006], and forms of civic association, freedom of speech, and communication have been ensured, it can be argued that the emphasis is on the implementation and protection of rights within the context of representative democracy, and much less so on a further strenghtening of civil society, expansion of civic input, the stimulation of substantive participation, and the promotion of forms of direct democracy (such as referenda) [cf. Rose-Ackerman 2005].

The emphasis in the constitutionalization of democracy has been on the creation of stability, the limitation of arbitrary state power, and the promotion of legal certainty and coherence. This all amounts to a clear-cut invocation of a rights-based form of legitimization of constitutional democracy. Rights-based legitimation was admittedly not the only form of legitimation, as it was often complemented by an identity-based, symbolic type of legitimization, which favours social integration and cohesion. But a third type of democratic legitimation, which could be referred to as substantive participation (in itself grounded in an idea of selfrule/autonomy or 'input-oriented legitimation') seems to have been increasingly marginalized in Central and Eastern European democratization [cf. Regulska 1993]. In this, the emphasis of constitutional actors was much less so on the facilitation of ongoing civic participation, forms of (local) self-government, and civic voice by means of referenda [for the cases of Hungary, Poland, and Romania, see Blokker 2009a]. Participatory dimensions, popular democracy, and civil society promotion, even if certainly not wholly absent from constitutions in the region, seem then to ultimately have an only secondary priority in constitutional hierarchies. This is further confirmed by the suggestion that such a one-sided attention for democratic stability

${ }^{10}$ See, however, for some indications of its continuing significance in a constitutional sense [Blokker forthcoming b]. 
and the rule of law was additionally reinforced by EU conditionality [Malova \& Dolny 2008].

As noted, this development is in a way surprising in that in at least in some societies, as is well-known (in particular in Hungary, the Czech Republic, and Poland), strong calls for self-rule and civic engagement were expressed in the years prior to the collapse of communism, and have played an important role in its demise. Dissident ideas indeed included the endorsement of forms of substantive, self-conscious civic participation, more direct forms of democracy, as well as political dissent [cf. Klingsberg 1992; Blokker 2009a, forthcoming b; Přibáň 2002], as it was, for instance, expressed in the constitutional draft of the Civic Forum in Czechoslovakia, or in Solidarity's programme of self-government ('The Self-Governing Republic'). Such an emphasis on civic participation is not easily reconciled with a one-sided legalist interpretation of constitutionalism. Nevertheless, in particular in the new democracies' context of widespread civic apathy and distrust in politics, participatory democratic channels would seem to be in need of positive endorsement [cf. Rose-Ackermann 2005]. This could be importantly done, even if not only so, through constitutional arrangements [Klingsberg 1992, 881]. The problématique of participation in the new democracies - clearly subject to forms of civic disenchantment and distrust in formal politics - consists then in the fact that in the new constitutional democracies a fairly strong tension exists between a dominant language of legalism, fundamental rights, and the rule of law, on the one hand, and the need to find ways of civic inclusion, civic participation and self-rule, and local government, on the other.

\section{Exploring Democratic Potentialities}

Modern constitutionalism tends to 'presuppose the uniformity of a nation state with a centralised and unitary system of legal and political institutions' [Tully 1995, 9]. Constitutionalism in the new democracies can for a good part said to be grounded in such a modern, and, as indicated above, in a number of significant ways increasingly obsolete or anachronistic conception, of 
constitutionalism ${ }^{11}$. The predominant interpretation of modern constitutionalism in the region involves a liberal, legal understanding of constitutionalism, and an unusual emphasis on the principle of sovereignty, the higher-law status of the constitutions, and their safeguarding by powerful constitutional courts [Albi 2007, 32-33].

\section{Four Tensions}

I will here briefly recap the problématiques outlined above that illustrate the potentially anachronistic dimensions of Central and Eastern European constitutionalism, before turning to possible, democratic remedies. The four problématiques of a modern understanding - state-centrism, cultural identity, depoliticization, and civic exclusion - render the new constitutional democracies less democratic, and less open to cultural diversity, ideational pluralism, and civic participation. But what is more, the four problématiques can be said to induce a form of constitutional anomie, in that existing constitutional orders are in important ways increasingly out of touch with a European-wide reality of post-nationalism, cultural diversity, civic disenchantment, and calls for civic voice.

First, it is by now widely acknowledged that the modern state is not anymore capable of acting as a contained and coherent steering mechanism in an increasingly globalized world, and that it cannot be seen as a closed framework for citizenship and democratic politics anymore [Walker 2002, 319]. In other words, modern constitutionalism is state-centred at a moment in which it has become increasingly clear that the sovereignty of state units cannot be taken for granted anymore, and needs to be seen in the context of a much more complex picture of multiple and overlapping sovereignties, particularly so in the European context. This discrepancy leads to problems of accountability, democratic legitimacy, equality, and civic input. This discrepancy is even more distressing in societies that have fairly recently embarked on revolutions that had as their explicit aim the institutionalization of democratic, autonomous regimes [cf. Howard 2009].

${ }^{11}$ For a concise discussion of constitutionalism in the light of three significant trends of pluralism, see [Blokker forthcoming a]. 
Second, modern constitutionalism expresses culturally homogeneous identities when societies are showing to be increasingly culturally pluralistic, and cultural groups to be increasingly engaged in cross-border interaction. In this, modern constitutionalism has difficulties in accommodating cultural diversity and claims of cultural recognition. Problems around issues of cultural diversity have (re-)emerged with force in the post-communist societies, in which issues of cultural identity had for a long time been repressed or manipulated by the party-state. Current tensions on the basis of claims for cultural recognition and pluralism are an important factor of protracted conflict in the new democracies (such as in the cases of Romania and Slovakia). Among intractable problems are the unitary perception of the state, a homogeneous, majoritarian idenity, and the lack of constitutional co-authorship of national minorities. These can be seen as immanent features of modern constitutionalism [cf. Lindahl 2008]. Demands for cultural pluralism and regional selfgovernment are in this unitary mindset too easily dismissed as threats to democracy and as favouring fragmentation and disintegration [cf. Tully 1995, 9; 2008].

Third, modern constitutionalism is depoliticizing politics in a moment of widespread civic disengagement and disillusionment in politics. The trend towards depoliticization and the externalization of constitutionalism (i.e., a foundationalist, prepolitical view of the premises of constitutional regimes) adds up to the hollowing out of democratic politics by removing foundational values and constitutive matters from political debate, and by equalizing democracy with the legal guardianship of pre-political values by a supposedly neutral, judicial authority. The view that new constitutionalism is to provide the firm bedrock of democratic transformation, and that Constitutional Courts are guarding and expanding democratic rights, tolerance, and cultural and religious diversity is, however, ambiguous. As argued by Wojciech Sadurski, robust judicial review might even have a 'negative educational effect': 'it may help to generate the perception that the rights discourse is an obscure activity reserved for lawyers, and that deliberation about the political values that give rise to specific articulations of rights is something over which neither the population nor its elected representatives have any control' [2005, 
20]. The anxiety to fix the rule of law, the Rechtsstaat, and fundamental rights once and for all after the experience of arbitrary and non-functioning 'socialist legality' might then backfire in that politics is emptied up to the extent that the fundamental rules - and identity - of the polity are not open for debate, and democratic participation is reduced to the retrieval of rights, but does not include any meaningful deliberation over their meaning.

Fourth, modern constitutionalism emphasizes stability, representation, and elitism in a moment in which deliberation, participation from below, and intra-societal dialogue are increasingly seen as indispensable for democratic legitimacy [cf. Dryzek 2004]. In this, modern, state-centred constitutionalism is too much biased towards public institutions and instituted political society, and much less so takes into account non-state, civic and private forms of participation in sovereignty and constitutional debate. Modern constitutionalism might be seen as simply too much 'dominated by the image of public institutions holding the centre of political and economic life' [Walker 2002, 323-4, 323; Rosanvallon 2006].

\section{Possible Remedies?}

While it is difficult to completely sidestep the epistemic image of a rights-based, liberal constitutional framework, which indeed seems indispensable to a modern democratic regime (for instance, in its providing for participatory rights), this does not mean that its hold necessarily exhausts the notion of constitutional democracy as such [cf. Blokker 2010]. In other words, a normative extension of a such a minimal constitutionalist regime points to the possibilities of 'civic' or 'grassroots' constitutionalism [cf. Skapska 1999], which involve intra-societal deliberation on constitutional norms, as well as a variety of channels for civic participation in such constitutional deliberation ${ }^{12}$. One definition of such a participatory, civic and post-modern type of constitutionalism is provided by Grazyna Skapska: 'a process of slow formation of constitutional principles "from below", in the

12 Beyond parliamentary engagement one could point to, for instance, constitutional referenda, Ombudsmen, and citizens' initiatives. 
every-day experience of citizens participating in local governments, non-governmental organizations, associations, and ethics commissions whose members participate in the decisionmaking processes or in conflict resolution, and construct their bylaws' [1999, 168].

In the light of these intrinsic problems of modern constitutionalism, it seems imperative to, first of all, study more comprehensively and closely than has been done so far ${ }^{13}$ to what extent the new constitutional orders and cultures in the postcommunist societies are able to engage in, and offer instruments for, developing more flexible and reflexive ways of dealing with contemporary and future challenges in terms of pluralism, multiple levels of sovereignty, supranational integration, constitutional change, civic participation, and local selfgovernment. In this regard, a comparative engagement with the constitutional role of notions of subsidiarity, (national) identity, supremacy of international and European law, constitutional amendment, civil spheres, as well as local forms of governance in the region could provide a picture as to what extent these constitutional orders are indeed anachronistic and unfit for the post-nationalist age, or might have some means to confront a novel situation ${ }^{14}$.

With regard to the state-centredness of Central and Eastern European constitutions, its traditionalist focus on the state as the pinnacle of constitutionalism is evident enough [cf. Albi 2005], but this in itself does not deny the existence of any parallel constitutional values and narratives that indicate alternative ways of understanding constitutionalism [cf. Blokker forthcoming b]. In a fairly simplistic, but for preliminary research sufficient distinction, one could look at to what extent the constitutions of the new democracies make it possible to deal flexibly and adequately with the international (notably EU) and global levels, on the one hand, and the subnational, regional and local levels, on the other.

13 See, however, for excellent studies in this direction (without, however, systematically looking for specific instruments or forms of constitutionalism fit for the post-national age): Albi [2005]; Sadurski [2003]; Přibáň and Young [1999].

14 The examples from various post-communist countries I will provide below are unsystematic and fairly scattered, but I believe, nevertheless significant, evidence of the availability of potential means to confront the post-national age. 
Regarding the level beyond the nation-state, it has often been argued that a process of polycentric globalization affects nationstates and their constitutions in a variety of (often deemed negative) ways [cf. Teubner 2003]. It can then be argued that the constitutions of the new democracies would, first of all, need to recognize the existence of competing forms of constitutionalism (in terms of civic, private, as well as international and global forms), and, where possible, to accommodate these, but also, and more importantly, to provide effective means to act against significant erosion of popular sovereignty.

The most clear-cut case of a post-national impact on the new democracies is obviously European integration, and advancing European constitutionalization. In the EU context, one futureoriented (but not uncontested) approach would be the active participation in the development of a European constitution, the explicit acknowledgement and accommodation of EU law in national law, and the attempt to devise a form of post-national constitutionalism that would be able to withstand global 'constitutional competition' [cf. Habermas 2001]. The most effective approach - suitable for the age of legal pluralism - has been identied as 'co-operative constitutionalism' or 'judicial dialogues' [Albi 2007, 27]. A contrasting, and largely preservative and probably ineffective and conflictive approach (although this is evidently debatable), would be the attempt to protect national constitutionalism from external encroachment, and try to keep national prerogatives in place [cf. Albi 2005; Sadurski 2008].

So far, the attitude towards 'co-operative constitutionalism' in the region has been evaluated as complex and ambivalent. On the one hand, a number of observers has argued that both the constitutional texts and the approach taken by Constitutional Courts in the region show an unusually strong attachment to the supremacy of national constitutions, and to the principles of sovereignty and independence, and a reluctance to grant Community law supremacy [Albi 2007; Sadurski 2008]. On the other hand, as shown by Anneli Albi [Albi 2007], it can be argued that Constitutional Courts have attempted to engage in interinstitutional dialogue and mutual co-operation in order to avoid conflicts between the European and national levels, and in this, endorse a common search for commonly held principles and the 
limits of a plurality of jurisdictions. The latter indicates the availability of a favourable attitude (at least of constitutional actors) towards strengthening a post-national, EU-wide constitutional project that attempts to deal with contemporary complexity.

On the substate level, there is a potential tension between a state-centric and centralist view as immanent in modern constitutionalism and visions of local self-governance, subsidiarity, and pluralistic views of self-determination. This tension is particularly prominent in post-communist societies, where the revolutions of 1989 were in many countries understood as an appropriate occasion to counter the hierarchical structures of 'democratic centralism' [Regulska 1993, 133-34]. The drive towards local self-governance in the immediate post-1989 period was evidently inspired by dissident ideas with a republican character, but equally coincides with increasingly popular WestEuropean ideas of local democracy, decentralization, and regionalism. It can then be argued that centralistic trends in modern constitutionalism can be importantly countered by novel forms of civic engagement and local self-government, which might provide antidotes to centralism, but also to the fragmented nature of post-Westphalian sovereignty and increasing civic alienation.

It needs to be recognized that in the twenty years that have passed since 1989, the predicament of civic and participatory democracy in Central and Eastern Europe has increasingly been evaluated in negative terms. But, in this, alternative, and to some extent promising, tendencies - sometimes related to (dissident) participatory legacies of the past, sometimes to the corrolaries of European integration - have been often overlooked [cf. Blokker forthcoming b]. Available alternative narratives of constitutional demcocracy in the region hold that disenchantment with democratic politics should be countered by means of the stimulation of political subjectivity in civil society [Klingsberg 1992]. This implies that the state needs to set limits on its own interference, and that traditional parliamentary and party politics needs to be supplemented by civic initiatives [cf. Skapska 1999, 169]. 
While quite a number of attempts to promote such a vision in the early 1990s has foundered, the same attempts have also often left constitutional 'traces' as well as embedded a democratic narrative that might potentially be, and on some occasions have been, re-activated ${ }^{15}$. In the Czech Constitution of 1992, for instance, constitutional traces of dissident ideas of civic participation are evident. As Magdalena Hadjiisky argues, one of such traces in the Czech Constitution regards the emphasis on territorial decentralisation, local civic autonomy, and the qualification of local self-government a 'fundamental constitutional rule' [Hadjiisky 2001, 48; cf. Pontuso 2002].

A similar, civic-democratic narrative of local autonomy can be found in Hungary, where it equally has had important formal-legal implications. Thus, in 1990, legislation was adopted that established a 'very high degree of autonomy for the lowest, local level of government', while the constitution enshrined the right to self-government at local and county levels as a constitutional principle [Fowler 2001, 8; cf. Jenei \& Szalai 2002; Blokker 2009a, 108]. In this, Hungarian decentralization is often mentioned together with the case of Poland, where the decentralisation of local government has arguably been a success [Regulski 2003] and one of the most effective in the region [cf. Wollmann and Lankina 2003, 116-117]. Also in the Polish case, the attention for local self-government and civic participation is clearly related to the dissident (Solidarity) legacy, even if the latter's original idea of a 'self-governing republic' has never been realized in any extensive way. On the one hand, then, it can be argued that 'local selfgovernment in Poland found a permanent place within the posttransformation political landscape' (also by means of its constitutionalization in Chapter VII of the 1997 Constitution), but at the same time, tendencies at recentralization and civic disinterest can be detected [Regulska 2009]. What is significant, though, is that tensions over local self-government, and appropriate relations between the centre and periphery continue to exist, indicating the unsettled nature of local democracy.

15 That liberal, legal constitutionalism in the region is by no means a settled understanding becomes clear from the fact that constitutional democracy remains a controversial issue in many of the new democracies, and frequent disputes over constitutional revision are widespread [cf. Pontuso 2002; Blokker 2009a]. 
With regard to the second problematique, the immanent drive towards cultural uniformity in modern constitutionalism, there is a clear tension between the cultural homogeneity of a majority nation with the plurality and cultural diversity that many, if not all, of the Central and Eastern European societies display [cf. Geroe \& Gump 1994]. Obstinance by national majorities to provide explicit (including constitutional) acknowledgement of the multicultural nature of their states clearly continue to fuel intercultural tensions and constitutional conflict.

The uniformity and cultural homogeneity - either implicit (e.g., in terms of language stipulations) or explicit (in terms of definitions of national identity and citizenship) - that designates typical modern constitutions can, however, be moderated by forms of a mutual recognition of identities (rather than a onesided imposition), and by the accommodation of cultural plurality, and its transformation, by means of a continuous constitutional dialogue and mutual formulation of shared constitution values [cf. Kymlicka and Opalski 2001]. The emphasis in this would be less on the formal 'co-existence' of various cultural groups in constitutional democracies, united by an existing constitution, but rather on the facilitation of 'co-authorship' of the rules of the political community [Blokker 2008, 370; Ringelheim 2010].

Such facilitation comprises at least two forms of pluralistic accommodation. First, the definition of a common identity would need to be pluralistic and dynamic. The pluricultural nature of modern polities would need (explicit) constitutional recognition, while the underpinning idea of culture and cultural identity would need to recognize the 'overlapping, interacting, and contested' nature of human cultures [Tully 1995, 186]. In other words, a cultural identity should not be fixed once and for all on the constitutional level, and intercultural dialogue needs to be facilitated.

That definitions which go some way towards a pluralistic, multi-national view are not wholly absent from the region (in contrast to sweeping statements on the region's historical inclination towards ethnocultural forms of nationalism) is shown by the example of constitutional accommodation of cultural pluralism and 'co-authorship' in the Hungarian Constitution. The latter states in article 68 (1) that '[t]he national and linguistic 
minorities in the Republic of Hungary shall share in the people's power, being constituent elements of the state' (emphasis added). This constitutional definition clearly goes against unitary and homogeneous understandings of an ethno-cultural majority nation, and should be understood in concommittance with the constitutional stipulation of a fairly wide range of negative and positive minority rights. In a sense broader than constitutional coauthorship, then, Hungary has sometimes been depicted as a frontrunner in the endorsement of internal cultural pluralism, in particular in the form of (collective) minority rights, and as having a 'strong constitutional framework within which to provide for the collective protection of minority rights' [Geroe \& Gump 1994, 673; cf. Přibáň and Sadurski 2006] ${ }^{16}$.

Second, culture-sensitive constitutions would need to recognize the plural cultural nature of existing polities by means of specific (in some cases, group) rights, forms of decentralization and local autonomy, and instruments for intercultural interaction and communication. Apart from the Hungarian case, a further interesting one is that of Romania, where from the adoption of the 1991 Constitution onwards there has been continuous (including constitutional) conflict over unitarian definitions of the Romanian state. The Romanian 1991 Constitution has been defined as reflecting a form of 'constitutional nationalism' as, among others, it contains in article 1 an unambiguous (and difficult to amend) unitarian definition of the Romanian state [Blokker 2009a]. By 2003, however, in anticipation of EU membership, a few fairly fargoing concessions to minority rights and participation have been included in the amended Constitution. The articles 120 (2) and 128 (2) contain a significant extension of the usage of the mother tongue of minorities in

16 The existence of an open, pluralistic constitutional definition does, unfortunately, not mean that in legal reality homogenizing views of nation are wholly absent, as is, for instance, visible in Hungarian citizenship law [cf. Přibáň 2007; Blokker 2009a]. Indeed, the Hungarian constitutional arrangement has been criticized for not effectively implementing minority rights, and for equally containing (latent) forms of ethno-nationalism. The latter aspects can, nevertheless, be put in a milder light if one accepts the view that nationalist tendencies are moderated by the fact that Hungarian nationalists and populists seem by now to have accepted a 'rights' language, to the detriment of revisionism, and are counterposed by non-nationalist political groups which play an important role in Hungarian politics [Kis 2001]. In other words, there might be room for further 'learning processes', partially induced by current constitutional arrangements. 
interaction with public institutions (the public administration and judiciary institutions). In addition, article 33 on the right to access to culture has been introduced. This right refers to access to national culture, and the promotion of Romanian culture in the world (33 (3)), and could in that sense be seen as emphasizing an 'ethic of identity' [see Blokker 2009a], but this right is also extended to national minorities, stipulating an individual right to access to culture, and therefore expanding the available set of rights [Constantinescu et al. 2004, 70-71].

The third problematique, that of the depoliticized nature of democracy in the Central and Eastern European region, resulting from the judicialization of (constitutional) politics, the prepolitical status of rights, and a certain subjection to EU supremacy, can be (partially) reversed or adjusted by a repoliticization of (constitutional) politics. The judicialization of constitutional politics has been contested as being indefensible in terms of both its legitimacy and its effectiveness [Bellamy 2007]. In order to correct an exaggerated hold of the judiciary over constitutional politics, terrain would need to be regained in terms of parliamentary politics, as well as of civic participation, beyond the monism of judicial predominance. In other words, a comparative review of the region's constitutions would need to take into account to what extent elected institutions deliberate on and are involved in constitutional matters, and in cases of very strong Constitutional Courts, to what extent and under what conditions a political engagement might be expanded. But this would probably not be sufficient to repoliticize constitutional politics effectively. It needs further to be assessed to what extent constitutions are actually facilitating public deliberation over, and interference into constitutional matters [by means of, e.g., public debate, 'constituent assemblies from below', referenda, and citizen initiatives, see Colon-Rios 2009; Hart 2003; Tierney 2009]. A truly democratic approach to constitutionalism would transcend the foundational, fixed nature of modern constitutionalism, and instill a deliberative and participatory element [cf. Hart 2003].

It can hardly be denied that there is a clear rationale for the insistence on a form of 'negative constitutionalism' in the postcommunist societies - with a bill of rights and judicial review at its core - i.e., the 'primarily negative purpose of preventing tyranny' 
[Holmes 1993, 23]. But any form of rights foundationalism which in Central and Eastern Europe is manifested in a (variegating) tendency to entrench rights in constitutions that subsequently can be interpreted only by Constitutional Courts - is difficult to uphold in the light of the 'essentially contestable' nature of rights [cf. Ferry and Renaut 1992; Kis 2003; Rosenfeld 2006; Sadurski 2003b], and, more importantly, might produce counterproductive or 'counterconstitutional' effects [cf. Sadurski 2005; Albert 2008]. The myth of a pre-political content of rights that can be fixed once and for all in constitutional documents, and of which Constitutional Courts are the best interpreters, contributes to a further alienation of citizens from democratic politics, and prevents the diffusion of constitutional and rights reasoning throughout a wider political culture. Rights, as well as other constitutional values, should rather be part of public debate as well as civic participation in (constitutional) politics. This could also include intermittent redefinition (even if this process could itself be subject to rather strict limitations and specific procedures).

In more concrete terms, the furtherance of constitutionaldemocratic legitimacy would need wider civic participation in constitutional politics; in other words, a form of 'democratic constitutionalism' [see Arato 2000; Tully 2008]. The need for this in itself depends in part on the level of constitutional insulation in any given constitutional order, and in particular on the specific amendment rules of the constitution. In this regard, as a useful normative yardstick, one might follow three desiderata for civic constitutional participation, as suggested by Andrew Arato [Arato 2000, 196-197; cf. Blokker 2009b]. Arato's original proposal regarded the specific Hungarian context in the early 1990s, but can, I believe, be taken to have a more general significance.

Civic participation in constitutional politics would need, first of all, the 'continuation of the original East European method of constitution making,' i.e., a political commitment to radical change without, however, violating the principle of legality. The acts of constitution-making in the region (in particular in Hungary and Poland) - through Round Tables, legal continuity, and Constitutional Courts - can be seen as providing promising 
foundations in terms of pluralistic participation [cf. Arato 2009] ${ }^{17}$. The essence of Arato's suggestion to seriously consider the 'East European method' is to reflect on 'what is needed to bring the process [of constitution-making, $\mathrm{pb}$ ] to an always provisionally close and how future access can be opened up in such as way that civil society preserves a potential influence over constitutional change' [Arato 2000, 195-6].

Second, Arato suggests the broadening of the sphere of politics by means of the guarantee of a plurality of constitutionally relevant political agents, which means that the fundamental rules of the polity need to be open to "the creative input of a wider range of social forces." Nevertheless, as observed earlier, in the current situation in most of the new member states, variegated and direct civic participation in the amendment of the foundational rules - complementary to formal political actors - is most of the time restricted. In, for instance, the Hungarian case, constitutional change can only be initiated by two-thirds of the parliament, while in Romania the civic pathway is formally available, but in reality extremely difficult to complete. In Poland, civic voice in constitutional matters is possible, but only on initiative of the Sejm, the senate or the president [Blokker 2009a, chapter 7].

And third, in order to improve the legitimacy of democratic politics, it is important to provide the "opportunity also for the less-formalized participation [in constitutional politics, pb] of the public by individuals and concerned organizations" in order to create a "Tocquevillian moment of constitution making", in particular by means of public discussion and forms of deliberation. That attempts to induce civic participation are not wholly absent in the region is shown by the example of Romania, where in an attempt to stimulate wider, societal deliberation on constitutional amendment by citizens and components of civil society, a so-called Constitutional Forum was organized in the run-up to the amendment of the Constitution in the context of EU membership in 2003.

17 It should be admitted, though, that a more inclusive and pluralistic type of constitutional politics has not persevered afterwards, in that none of the constitutions in the region offer wide-ranging possibilities for civic engagement in constitutional change, and if they do, it is often under rigid conditions (as, for instance, in the Romanian case). 
A common normative thread regarding solutions to all the problématiques mentioned above - state-centrism, cultural diversity, and depoliticization - points to the importance of civic engagement, not least regarding constitutional norms and rights. This brings us to the final problématique, that is, the extent that existing constitutions actually facilitate forms of civic participation in politics in general [cf. Albert 2008]. It can be argued that a democratic form of constitutionalism cannot be confined to a legal, reductionist view of constitutions that perceive the role of the latter in a purely negative light. Rather, if constitutionalism is to be democratic, it needs to provide ways for citizens to be involved in the formulation and revision of the rules and norms that govern a polity.

As observed earlier, despite a diffused adherence to a legalfoundationalist view of constitutionalism, some significant ideational legacies of civic participation and direct forms of democracy clearly also exist in the Central and Eastern European region, and have contributed directly to the demise of communism [cf. Dryzek and Holmes 2002; Přibáń 2002]. It would indeed be surprising if none of these ideas had been upheld in the wake of 1989, and if a legalist reading of democracy would have exhausted the profound changes in the region. As observed above, it seems ultimately more accurate to argue that, while the legalist dimensions in Central and Eastern European processes of constitutionalization were predominant, other, more civically conducive dimensions are not insignificant either [cf. Sadurski and Přibán 2006, 215-19; Blokker forthcoming b]. The dimension of civic participation and forms of direct democracy in the context of constitution-making seem to have been in many ways ignored by observers, but have not altogether disappeared from the constitutional scene, and in have some cases even been revived ${ }^{18}$. In this regard, the thesis that civil society as a discourse and practice has been widely compromised since 1989 is not accurate and overpessimistic, also since a number of positive engagements

\footnotetext{
${ }^{18}$ In Hungary, for instance, the much overdue regulation of referenda in 1997 led to the constitutionalization of fundamental rules regarding referenda. At least in a formal sense, this can be interpreted as an increase in the status of direct democracy in the Hungarian constitutional order [Dezsö \& Bragyova 2007: 70].
} 
with the (constitutional) facilitation of civic participation can be pointed out [see above; cf. Arato 2000, chapters 2 and 4].

Ideas of civic participation, self-rule, and local self-government have had some significant impact on the post-1989 constitutional orders. In the early 1990s, Ethan Klingsberg already elaborated on the role constitutional rules can play in endorsing civic participation while observing some positive trends in Hungary [Klingsberg 1992], while probably the most optimistic expert on civil society in the region, Andrew Arato, noted that 'reports concerning the demise of civil society turned out to be premature' and that 'constitutional arrangements facilitated in various ways and degrees the reemergence of civic associations and initiatives and their reinsertion into national politics' [2000, 70-71]. A significant instance is in this sense the Polish case, as pointed out by Ewa Popławska [1997; see for the wider Central and Eastern European context, Bruce 2006]. Popławska emphasizes the importance of the idea of subsidiarity in Polish constitutionalism, an idea which can be seen as closely related to ideas of civic autonomy and self-government. Subsidiarity is one of the fundamental principles of the Polish constitution of 1997, and, even if it is only explicitly mentioned in the preamble, it provides a normative indication and is reflected in the actual text in various ways. In this, Popławska has argued that subsidiarity in the context of constitutional law can be related to three principles: pluralism, decentralization, and democracy or self-government. Reflections of subsidiarity can be found in both the Small Constitution of 1992 and in the 1997 Constitution (in significant articles related to the common good, civil society, citizens' initiatives, and local self-government), and its intriguing, even if ambiguous, pedigree can be related to not only European integration ${ }^{19}$ and Catholic thought, but also dissident ideas of the 1980s.

The problématique of civic participation and self-government points at a predominance of legal constitutionalism, state-centred politics, and a representative understanding of democracy that

19 In the context of European integration, discussions of 'co-operative constitutionalism' regarding the relation between supranational and national levels are clearly related to the notion of subsidiarity. 
clashes with more participatory, civic forms of constitutionalism and of politics in general, or that at the very least might exacerbate widespread civic disenchantment with politics. One way of contributing to some resolution of the paradoxes pointed out at the beginning of the paper would be research that steers away from one-sided attention for legal modern constitutionalism, rights entrenchment and application, and the rule of law, and that engages in further investigations into the endurance of dissident legacies, including the less visible, but not necessarily negligible participatory dimensions of the current constitutional regimes. These dimensions would need to include such issues as the stimulation of civic association through constitutional guarantee, civic access to national legislative and local referenda, and extensive and effective forms of decentralization and selfgovernment ${ }^{20}$.

\section{Concluding Remarks}

I have argued that the new democracies in Central and Eastern Europe have adopted known and tested models of constitutional democracy (even if with distinctive features), leading their societies away from the vagaries of 'socialist legality' towards stable, democratic orders. However, the trajectory of modern constitutionalism brings with it - in a post-Westphalian era - a number of problématiques that threaten some of the core features of that very same constitutional model. This means that in some ways one can speak of a situation of constitutional anomie, as tensions have emerged in the region with regard to the statecentric focus and perception of national sovereignty of modern constitutionalism, as well as with regard to homogeneous formulations of collective identity. What is more, there are strong tendencies in the new member states towards a legalistic rather than a democratic interpretation of constitutionalism, visible in terms of the judicialization of democracy as well as in a predominance of legal-formalistic over democratic-participatory understandings of constitutionalism. But, at the same time, there

${ }^{20}$ See, for one of the very few contributions in this area, Auer and Buetzer [2001]. 
are signs of democratic potentiality and pluralism in the existing constitutional orders, that, if strengthened and explicated, might increase the legitimacy and societal embeddedness of the new constitutional democracies and render them more apt for the post-Westphalian era. 



\section{REFERENCES}

Ackerman, B.

1992 The future of liberal revolution, New Haven, Yale University Press.

Albert, R.

2008 Counterconstitutionalism, in «Dalhousie Law Journal», 31, pp. $1-54$.

Albi, A.

2005 EU enlargement and the constitutions of Central and Eastern Europe, New York, Cambridge University Press.

2007 Supremacy of EC Law in the New Member States. Bringing parliaments into the Equation of "Co-operative Constitutionalism", Arato, A. in «European Constitutional Law Review», 3, 1, pp. 25-67.

2000 Civil society, constitution, and legitimacy, Lanham, Md., Rowman \& Littlefield.

2009 Redeeming the Still Redeemable: Post Sovereign Constitution Making, in «International Journal of Politics, Culture \& Society», 22, pp. 427-443.

Arjomand, S.A.

2003 Law, Political Reconstruction and Constitutional Politics, in «International Sociology», vol. 18(1), pp. 7-32.

Auer, A. and Buetzer, M. (eds)

2001 Direct Democracy: The Eastern and Central European Experience, Ashgate.

Augenstein, D. and Hendry, J.

2009 The "Fertile Dilemma of Law": Legal Integration and Legal Cultures in the European Union, Tilburg Institute of Comparative and Transnational Law, «Working Paper 2009/06». 
Bellamy, R.

2007 Political constitutionalism: a republican defence of the constitutionality of democracy, Cambridge, Cambridge University Press.

Blokker, P.

2008 Rights, Identities, and Democracy in a Post-Enlargement European Union, in «Perspectives on European Politics and Society», 9(3), pp. 357-374.

2009a Multiple Democracies in Europe: Political Culture in New Member States, London/New York, Routledge.

2009b Democracy Through the Lens of 1989: Liberal Triumph or Radical Turn?, in «International Journal of Politics, Society, and Culture», 22(3), pp. 273-290.

2010 Democratic Ethics, Constitutional Dimensions, and Constitutionalisms, in A. Febbrajo \& W. Sadurski (eds.), East-Central Europe After Transition: Towards a New Socio-legal Semantics, Ashgate, pp. 73-98.

forthcoming a Modern Constitutionalism and the Challenges of Complex Pluralism, in G. Delanty and S. Turner (eds), The Handbook of Contemporary Social and Political Theory, Routledge.

forthcoming b Dissidence, Republicanism, and Democratic Change, in special issue on 'Democracy after 1989: Re-examining the History, Impact, and Legacy of Dissidence' (guest editors: Paul Blokker and Robert Brier), in «East European Politics and Societies».

Bruce, R.

2006 The Quest for Subsidiarity in Eastern European Nation Building, in «International Journal of Public Administration», 29, 13, pp. 1215-1227.

Colon-Rios, J.I.

2009 The End of the Constitutionalism-Democracy Debate, «CLPE Research Paper 03/2009», 5(1).

Constantinescu, M., Iorgovan, A., Ioan Muraru, and Tănăsescu E.S.

2004 Constituția României reviæuită. Comentarii și explicații, Bucharest, Editura All Beck.

De Raadt, J.

2009 Contested Constitutions. Legitimacy of Constitution-making and Constitutional Conflict in Central Europe, in «East European 
Delanty, G

Politics and Societies», Vol. 23, n. 3, pp. 315-338.

2000 Citizenship in a Global Age. Society, culture, politics, Buckingham/Philadelphia, Open University Press.

Dezsö, M. and Bragyova, A.

2007 National Referendums in Hungary, in A. Jakab, P. Takacs, A.F. Tatham (eds), The Transformation Of The Hungarian Legal Order 1985-2005 - Transition to the Rule of Law and Accession to the European Union, Kluwer Law International, pp. 68-82.

Dryzek, J.

2004 Democratic political theory, in Gerald F. Gaus \& Chandran Kukathas (eds), Handbook of Political Theory, Sage, pp. 143154.

Dryzek, J. and Holmes, L.

2002 Post-communist democratization: political discourses across thirteen countries, Cambridge/New York, Cambridge University Press.

Durkheim, E.

1997 The Division of Labour in Society, The Free Press.

Ferry, L. and Renaut, A.

1992 From the Rights of Man to the Republican Idea, Chicago University Press.

Habermas, J.

2001 Why Europe Needs a Constitution, in «New Left Review», 11.

Häberle, P.

1992 Verfassungsentwicklungen in Osteuropa - aus der Sicht der Rechtsphilosophie und der Verfassungslebre, in «Archiv des öffentlichen Rechts», Volume 117, Issue 2, pp. 170-211.

Hadjiisky, M.

2001 The Failure of the Participatory Democracy in the Czech Republic, in «West European Politics», 24, 3, pp. 43-64.

Hart, V.

2003 Democratic Constitution Making, «Special Report, United States Institute for Peace», available at: http:// www.usip.org.

Holmes, S.

1993 Back to the Drawing Board, in «East European Constiutional Review», pp. 21-25. 
Howard, D.

1995 Law and Political Culture, "Cardozo Law Review», 17, pp. 1391-1429.

2009 What is a Revolution? Reflections on the Significance of 1989/90, in «Logos», vol. 8, issue 2 http://www.logosjournal.com.

Fowler, B.

2001 Debating Sub-state Reform on Hungary's "Road to Europe", «Working Paper 21/01», CREES.

Grudzinska-Gross, I.

1997 Introduction: When Polish Constitutionalism Began, in «East European Constitutional Review», 6(2/3), pp. 64-76.

Geroe, M.R. and Gump, T.K.

1994 Hungary and a New Paradigm for the Protection of Ethnic Minorities, in «Columbia Journal of Transnational Law», 32, pp. 673-705.

Jenei, G. and Szalai, A.

2002 Moderniring Local Governance in a Transitional Nation: Evaluating the Hungarian Experience, in «Public Management Review», 4(3), pp. 367-387.

Keating, M.

2003 Regionalization in Central and Eastern Europe: the Diffusion of a Western Model?, in Michael Keating and James Hughes (eds), The Regional Challenge in Central and Eastern Europe: Territorial Restructuring and European Integration, Bruxelles, P.I.E.-Peter.

Kis, J.

2001 Nation-Building and Beyond, in W. Kymlicka and M. Opalski (eds), Can Liberalism be Exported?, Oxford University Press, pp. 220-243.

2003 Constitutional Democracy, Budapest/New York, CEUPress. Klingsberg, E.

1992 The State Building Civil Society: Constitutionalism and the PostCommunist Paradox, in «Michigan Journal of International Law», 13, pp. 865-907.

Kymlicka, W. and Opalski, M.

2001 Can liberal pluralism be exported?: Western political theory and ethnic relations in Eastern Europe, Oxford/New York, Oxford University Press. 
Lindahl, $\mathrm{H}$.

2008 Democracy, Political Reflexivity and Bounded Dialogues: Reconsidering the Monism-Pluralism Debate, in Emilios Christodoulidis, and Stephen Tierney (eds), Public law and politics: the scope and limits of constitutionalism, Aldershot, England/Burlington, Vt, Ashgate, pp. 103-116.

MacDonald, R.

1995 The Design of Constitutions to Accommodate Linguistic, Cultural and Ethnic Diversity, in K. Kulcsar and D. Szabo (eds), Dual Images: Multiculturalism on Two Sides of The Atlantic, Budapest, Royal Society of Canada - Hungarian Academy of the Sciences, pp. 52-84.

Malova, D. \& Dolny, B.

2008 The Eastern Enlargement of the European Union: Challenges to

Offe, C.

Democracy?, in «Human Affairs», 18(1), pp. 67-80.

1996 Varieties of Transition. The East European and East German Experience, Cambridge, Polity Press.

Piana, D.

2006 Constitutional Cultures in New Member States. Between Tradition and Europeanization, in Wojciech Sadurski, Jacques Ziller, Karolina Zurek (eds), Après enlargement: legal and political responses in Central and Eastern Europe, Florence, RSCAS, pp. 79-106.

Pontuso, J.F.

2002 Transformation politics: the debate between Vaclav Havel and $V$ aclav Klaus on the free market and civil society, in «Studies in East European Thought», 54, pp. 153-177.

Popławska, E.

1997 Principle of Subsidiarity under the 1997 Constitution of Poland, in Preda, C. «St. Louis-Warsaw Transatlantic Law Journal», 107.

2002 La Nation dans la Constitution, in Nation and National Ideology. Past, Present, and Prospects, Bucharest, New Europe College, pp. 390-445.

Přibáň, J.

2002 Dissidents of law: on the 1989 velvet revolutions, legitimations, fictions of legality, and contemporary version of the social contract, Aldershot, Hampshire, England/Burlington, VT, 
Ashgate/Dartmouth.

2005a Constitutional Symbolism and Political (Dis)continuity: Legal Rationality and Its Integrative Function in Postcommunist Transformations, in A. Czarnota, M. Krygier, and W. Sadurski (eds), Rethinking the Rule of Law after Communism, Budapest, CEU Press.

2005b Political Dissent, Human Rights, and Legal Transformations: Communist and Post-Communist Experiences, in «East European Politics and Societies», 19(4), pp. 553-572.

2007 Legal Symbolism. On Law, Time and European Identity. Aldershot, UK/Burlington, USA, Ashgate.

2010 Constituting the Heterarchy of European Constitutionalism in the EU's New Member States, in A. Febbrajo \& W. Sadurski (eds.), East-Central Europe After Transition: Towards a New Socio-legal Semantics, Ashgate, pp. 13-34.

Přibán, J. and Young, J. (eds)

1999 The rule of law in Central Europe: the reconstruction of legality, constitutionalism and civil society in the post-Communist countries, Aldershot/(Brookfield, Vt., Ashgate/Dartmouth.

Přibán̆, J. and Sadurski, W.

2006 The Role of Political Rights in the Democratization of Central and Eastern Europe, in W. Sadurski (ed.), Political Rights under Stress in 21st Century Europe, Oxford, Oxford University Press, pp. 196-238.

Regulska, J.

1993 Self-Governance or Central Control? Rewriting Constitutions in Central and Eastern Europe, in A.E.D. Howard (ed.) Constitution Making in Eastern Europe, Washington, DC, Woodrow Wilson Center Press.

2009 Governance or Self-governance in Poland? Benefits and Threats 20 Years Later, in «International Journal of Politics, Culture \& Society», 22(4), pp. 537-556.

Regulski, J.

2003 Local Government Reform in Poland: an Insider's Story, Budapest, OSI/LGI.

Ringelheim, J.

2010 Minority Rights in aTime of Multiculturalism. The Evolving Scope of the Framework Convention on the Protection of National Minorities, in «Human Rights Law Review», pp. 1-30. 
Rosanvallon, P.

2006 Democracy past and future, New York, Columbia University Press.

Rose-Ackerman, S.

2005 From elections to democracy: building accountable government in Hungary and Poland, New York, Cambridge University Press.

Rosenfeld, $\mathrm{M}$.

2006 A Pluralist Theory of Political Rights in Times of Stress, in W. Sadurski (ed.), Political Rights under Stress in 21st Century Europe, Oxford University Press, pp. 12-54.

Sadurski, W. (ed.)

2003a Constitutional justice, East and West: democratic legitimacy and constitutional courts in post-communist Europe in a comparative perspective, The Hague/New York, Kluwer Law International.

Sadurski, W.

2003b Constitutional Courts, Individual Rights and the problem of Judicial Activism in Postcommunist Central Europe, in J. Přibáń, P. Roberts \& J. Young (eds), Systems of Justice in Transition, Ashgate, Aldershot, pp. 13-28.

2005 Transitional Constitutionalism: Simplistic and Fancy Theories, in A. Czarnota, M. Krygier, and W. Sadurski (eds), Retbinking the Rule of Law after Communism, Budapest/New York, CEUPress, pp. 9-24.

2008 'Solange, chapter 3': Constitutional Courts in Central Europe Democracy - European Union, in «European Law Journal», Sajó, A. 14(1), pp. 1-35.

1990 New Legalism in East Central Europe: Law as an Instrument of Social Transformation, in «Journal of Law and Society», 17, 3, pp. 329-44.

2005 Constitution without the Constitutional Moment: A View From the New Member States, in «International Journal of Constitutional Law», 3(2-3), pp. 243-261.

Scheppele, K.L.

2004 Counter-constitutions: Narrating the nation in Post-Soviet Hungary, paper given at George Washington University, Washington DC, 2 April 2004. 
Scheppele, K.L.

2005 Democracy by Judiciary. Or, why Courts Can be More Democratic than Parliaments, in A. Czarnota, M. Krygier, and W. Sadurski (eds), Rethinking the Rule of Law after Communism, Budapest/New York, CEUPress, pp. 25-60.

Schwartz, H.

2000 The struggle for constitutional justice in post-communist Europe, Chicago, University of Chicago Press.

Skapska, G.

1999 Paradigm Lost? The Constitutional Process in Poland and the Hope of a "Grass Roots Constitutionalism", in Martin Krygier and Adam Czarnota (eds), The rule of law after communism: problems and prospects in east-central Europe, Aldershot/Brookfield, Vt., Ashgate, pp. 149-175. Stanger, A.

1995 Constitutional Transformation in Post-Communist Central Europe: A Liberal Revolution?, in Z. Suda and J. Musil (eds), The Meaning of Liberalism: East and West, Budapest, CEUPress, pp. 235-248.

Tănăsescu, E.S.

2008 Presidential Elements in Government. The President of Romania, Or: The Slippery Slope of a Political System, in «European Constitutional Law Review», 4, pp. 64-97.

Teubner, G.

2003 Societal Constitutionalism: Alternatives to State-centred Constitutional Theory, «Storrs Lectures 2003/04 Yale Law School».

Tierney, S.

2009 Constitutional Referendums: A Theoretical Enquiry, in «Modern Tully, J. Law Review», 72(3), pp. 360-83.

1995 Strange multiplicity: constitutionalism in an age of diversity, Cambridge/New York, Cambridge University Press.

2008 Public philosophy in a new key, Cambridge, Cambridge University Press.

Walker, N.

2002 The Idea of Constitutional Pluralism, in «Modern Law Review», 65(3), pp. 317-59. 
Walker, N.

2008 Taking Constitutionalism Beyond the State, «Political Studies», 56, pp. 519-543.

Wollmann, H. and Lankina, T.

2003 Local Government in Poland and Hungary: from post-communist reform to EU accession, in $\mathrm{H}$. Baldersheim, $\mathrm{M}$. Illner and $\mathrm{H}$. Wollmann (eds), Local democracy in post-communist Europe, Opladen, Leske + Budrich, pp. 91-123. 
Impaginazione a cura del supporto tecnico DSRS

Stampa a cura del

Servizio Stamperia e Fotoriproduzione

dell’Università degli Studi di Trento

2010 
I QUADERNI DEL DIPARTIMENTO DI SOCIOLOGIA E RICERCA SOCIALE costituiscono una iniziativa editoriale finalizzata alla diffusione in ambito universitario di materiale di ricerca, riflessioni teoriche $e$ resoconti di seminari di studio di particolare rilevanza. L'accettazione dei diversi contributi è subordinata all'approvazione di un'apposita Commissione scientifica.

Dal 2006 la collana comprende una sezione (serie rossa) dedicata ai contributi di giovani ricercatori e dal 2007 una serie verde riservata ai docenti e ricercatori ospiti del Dipartimento.

1 E. BAUMGARTNER, L'identità nel cambiamento, 1983.

2 C. SARACENO, Changing the Gender Structure of Family Organization, 1984.

3 G. SARCHIELLI, M. DEPOLO e G. AVEZZU', Rappresentazioni del lavoro e identità sociale in un gruppo di lavoratori irregolari, 1984.

4 S. GHERARDI, A. STRATI (a cura di), Sviluppo e declino. La dimensione temporale nello studio delle organizzazioni, 1984.

5/6 A. STRATI (a cura di), The Symbolics of Skill, 1985.

7 G. CHIARI, Guida bibliografica alle tecniche di ricerca sociale, 1986.

8 M. DEPOLO, R. FASOL, F. FRACCAROLI, G. SARCHIELLI, L'az̧ione negoziale, 1986.

9 C. SARACENO, Corso della vita e approccio biografico, 1986.

10 R. PORRO (a cura di), Le comunicaz̧ioni di massa, 1987.

11/12 G. CHIARI, P. PERI, I modelli log-lineari nella ricerca sociologica, 1987. 
13 S. GHERARDI, B. TURNER, Real Men Don't Collect Soft Data, 1987.

14 D. LA VALLE, Utilitarismo e teoria sociale: verso più efficaci indicatori del benessere, 1988.

15 M. BIANCHI, R. FASOL, Il sistema dei servizi in Italia. Parte prima: Serviri sanitari e cultura del cambiamento. A dieci anni dalla riforma sanitaria. Parte seconda: Modelli di analisi e filoni di ricerca. 1988.

16 B. GRANCELLI, Le dita invisibili della mano visibile. Mercati, gerarchie e clan nella crisi dell'economia di comando, 1990.

17 M. A. SCHADEE, A. SCHIZZEROTTO, Social Mobility of Men and Women in Contemporary Italy, 1990.

18 J. ECHEVERRIA, I rapporti tra stato, società ed economia in America Latina, 1991.

19 D. LA VALLE, La società della scelta. Effetti del mutamento sociale sull'economia e la politica, 1991.

20 A. MELUCCI, L'Aids come costrurione sociale, 1992.

21 S. GHERARDI, A. STRATI (a cura di), Processi cognitivi dell'agire organizzativo: strumenti di analisi, 1994.

22 E. SCHNABL, Maschile e femminile. Immagini della differenza sessuale in una ricerca tra i giovani, 1994.

23 D. LA VALLE, La considerazione come strumento di regolazione sociale, 1995.

24 S. GHERARDI, R. HOLTI e D. NICOLINI, When Technological Innovation is not Enough. Understanding the Take up of Advanced Energy Technology, 1999.

25 D. DANNA, Cattivi costumi: le politiche sulla prostiturione nell'Unione Europea negli anni Novanta, 2001.

26 F. BERNARDI, T. POGGIO, Home-ownership and Social Inequality in Italy, 2002. 
27 B. GRANCELLI, I metodi della comparazione: Alcuni area studies e una rilettura del dibattito, 2002.

28 M.L. ZANIER, Identità politica e immagine dell'immigrazione straniera, una ricerca tra gli elettori e $i$ militanti di An e Ds a Bologna, 2002.

29 D. NICOLINI, A. BRUNI, R. FASOL, Telemedicina: Una rassegna bibliografica introduttiva, 2003.

30 G. CHIARI, Cooperative Learning in Italian School: Learning and Democracy, 2003.

31 M. ALBERTINI, Who Were and Who are the poorest and the richest people in Italy. The changing household's characteristics of the people at the bottom and at the top of the income distribution, 2004.

32 D. TOSINI, Capitale sociale: problemi di costrurione di una teoria, 2005.

33 A. COSSU, The Commemoration of Traumatic Events: Expiation, Elevation and Reconciliation in the Remaking of the Italian Resistance, 2006 (serie rossa).

34 A. COBALTI, Globalizzazione e istruzione nella Sociologia dell' Educarione in Italia, 2006 (serie blu).

35 L. BELTRAME, Realtà e retorica del brain drain in Italia. Stime statistiche, definizioni pubbliche e interventi politici, 2007 (serie rossa).

36 A. ARVIDSSON, The Logic of the Brand, 2007 (serie verde).

37 G. M. CAMPAGNOLO, A sociology of the translation of ERP systems to financial reporting, 2007 (serie rossa).

38 LABOR - P. CAPUANA, E. LONER, C. PATERNOLLI, T. POGGIO, C. SANTINELLO, G. VIVIANI, Le ricerche di Petronilla. Una guida alle fonti statistiche per l'analisi secondaria nella ricerca sociale, 2007 (serie blu). 
39 A. SCAGLIA, 25 anni dell'Associazione di Sociologia. Materiali per scriverne la storia, 2007 (serie blu).

40 A. M. BRIGHENTI, Tra onore e dignità. Per una Sociologia del rispetto, 2008 (serie rossa).

41 S. BENATI, G. CHIARI, I meccanismi dell'apprendimento cooperativo: un approccio di scelta razionale, 2008 (serie blu).

42 A. COBALTI, L'istruzione in Africa, 2008 (serie blu).

43 P. WAGNER, The Future of Sociology:Understanding the Transformations of the Social, 2009 (serie blu).

44 A. COBALTI, L'istruzione in America latina, 2009 (serie blu).

45 P. BARBIERI, G. CUTULI, Equal Job, Unequal Pay. Fixed Term Contracts and Wage Differentials in the Italian Labor Market, 2009 (serie blu).

46 K. LIBERMAN with G. FELE, V. D'ANDREA, G.M. CAMPAGNOLO, Y. CURZI, G. VISCUSI, Phenomenology and the Social Study of Information Systems: Conversations with Kenneth Liberman, 2009 (serie verde).

47 B. GRANCELLI, Cooperative e sviluppo locale nelle regioni rurali dell'Europa Orientale. Paradossi dell'imprenditoria economica e sociale nella transizione, 2009 (serie blu).

48 P. ROSA, La svolta sociologica nelle relazioni internazionali: tre approcci e tre filoni di ricerca, 2010 (serie blu).

49 A. M. BRIGHENTI, The Publicness of Public Space. On the Public Domain, 2010 (serie rossa).

50 R. POLI, The Complexity of Self-reference. A Critical Evaluation of Lubmann's Theory of Social Systems, 2010 (serie blu).

51 A. COBALTI, India, 2010 (serie blu).

52 A. COBALTI, L'istruzione in India, 2010 (serie blu). 

Responsabile editoriale: Antonio Cobalti (antonio.cobalti@soc.unitn.it)

Responsabile tecnico: Luigina Cavallar

(luigina.cavallar@soc.unitn.it)

Dipartimento di Sociologia e Ricerca Sociale Università di Trento

Via Verdi, 26 - 38122 Trento - Italia

Tel. $0461 / 281322$

Fax 0461/281348

Web: http://portale.unitn.it/dsrs/ 


\section{Constitutionalism and Constitutional Anomie in the New Europe}

\section{Paul Blokker}

The recent (re-)establishment of constitutional democracies in Central and Eastern Europe is affected by a paradoxical situation: while modern constitutionalism was significantly strenghtened by the 'new constitutionalism' in the region, it is itself increasingly seen as out of touch with (pluralist) reality. In the paper, I explore to what extent it can be claimed that the new constitutionalism adopted in the former communist countries is a reinvigorated version of 'traditional' modern constitutionalism. To the extent that this seems indeed to be the case, I outline a number of problématiques or tensions that modern constitutionalism provokes in the current European context. These include four problématiques in particular: state-centrism, cultural diversity, depoliticization, and participation. In the third section, I will discuss possible solutions to or ways out of these four problématiques by hinting at, in a descriptive sense, insufficiently (or un-)explored dimensions of the Central and Eastern European constitutions. And in a more normative sense, I will at the same time indicate possible steps towards constitutional change that would, in my view, make current constitutional orders more amenable to challenges of pluralism, democratic legitimacy, and post-nationalism.

Paul Blokker is a postdoctoral fellow (PAT) at the department of Sociology and Social Research, University of Trento, Italy. His current research is on constitutionalisms, constitutional rationalities, plurality, and (local) democratic participation in the new member states of the EU. Publications include: 2009, Multiple Democracies in Europe. Political Culture in New Member States, Routledge and forthcoming, 'Dissidence, Republicanism, and Democratic Change', in: special issue on 'Democracy after 1989: Re-examining the History, Impact, and Legacy of Dissidence' (guest editors: Paul Blokker and Robert Brier), in: East European Politics and Societies. 